\title{
Investigation on the Head Injury in Different Restraint System Using A Six-Year-Old Child Occupant Finite Element Models with Accurate Anatomical Characteristics
}

\author{
Haiyan Li*, Jian Li, Shijie Ruan, Shihai Cui and Lijuan He \\ International Research Association on Emerging Automotive Safety Technology, Tianjin University of Science and Technology, China
}

Submission: March 11, 2019; Published: March 26, 2019

*Corresponding author: Haiyan Li, International Research Association on Emerging Automotive Safety Technology, Tianjin University of Science and Technology, Tianjin 30022, China

\begin{abstract}
To investigate the head injury in different Restraint system, a validated six-year-old child occupant finite element models with accurate anatomical characteristics was used to load ECE R44 testing conditions. The protective effects of the 6-year-old rear seat occupant on forwardfacing child seat restraint system and booster was discussed in different collision speeds through the resultant head acceleration, pressure, brain tissue Von Mises stress, brain tissue shear stress. The results indicate that: When the collision speed is low, there is little difference of the child finite element model's injury criterions in the two restraint systems, while the protective effect of child seat restraint system to the children is better than booster with the increase of the collision speed.
\end{abstract}

Keywords: Finite element model; Six-year-old child; Occupant protection; Child restraint system; Biomechanical injury

\section{Introduction}

According to the data from the National Highway Traffic Safety Administration (NHTSA), traffic accidents are the leading cause of death for children ages 1 to 13 years, more than 225,000 children are injured in traffic accidents each year, of which 25,500 are severely injured, and the head is the most vulnerable part [1]. In 2015, children under the age of 13 who died in car accidents accounted for $35 \%$ of all deaths, and most of them did not properly use child seats, boosters or seat belts, and 248 children less than 5 years old were rescued by using car safety seats. Since the 1950s and 1960s, developed countries such as Europe and the United States have begun to study the safety of children riding, and have established and implemented a complete legal system of child restraint system, such as ECE R44, CMVSS 208 and FMVSS 213. Compared with developed countries, the related laws and regulations for the protection of children occupants in China started relatively late. The first compulsory national standard on children's safety riding The Restraint System for Motor Vehicle Children's Occupants was established in 2003 and formally issued on July 1, 2012.

Although the popularity and usage of child restraint systems have increased dramatically over the past few years, many parents have not chosen age-appropriate restraint systems for their children. Because of the height and weight of children, adult 3-point seat belts cannot restrain children effectively, while car seats and boosters can provide good protection for children in traffic accidents.

Data from the European studies indicate that different types of child restraint systems have different levels of protection [2]. According to the recommendations of Durbin [3], children aged 1 to 6 can be restrained in forward-facing child seat restraints, and children aged 4 to 11 should use a booster to match adult 3-point seat belts. An analysis report of Volvo crash database in Sweden shows that rear-facing child restraints can provide maximum protection for children and reduce the risk of serious injury as high as $80 \%-90 \%$, forward-facing child restraints can reduce about $70 \%$, Compared with adult 3-point seat belts alone, elevated booster may also reduce the likelihood of injury in children, but it protection level is lower than other special child restraint systems [4]. This also illustrates the importance of proper selection and use of restraint systems to protect children occupants.

Tanya, et al. [5] analyzed the finite element model and Hybrid 3-year-old dummy's acceleration of head and chest, as well as the force and moment of neck under the same simulation 
conditions; they found that the maximum percentage error between experimental peak values and numerical predictions was determined to be no greater than 15\% [6]. placed a Hybrid 0 6-year-old dummy in a high back belt-positioning booster (with backrest), a backless belt-positioning booster (without backrest) and a lap shoulder seat belt respectively, compared and analyzed the protective effects of three different restraint systems on the 6 -year-old child occupant in the rear seat at speeds of $24 \mathrm{~km} / \mathrm{h}$, $40 \mathrm{~km} / \mathrm{h}$ and $56 \mathrm{~km} / \mathrm{h}$. The results show that when the speed is $24 \mathrm{~km} / \mathrm{h}$ and $40 \mathrm{~km} / \mathrm{h}$, the injury value of Hybrid ? child dummy in all the restraint systems has no obvious difference. The variation of performance was observed for the $56 \mathrm{~km} / \mathrm{h}$, where the 6-year-old dummy in the high back belt-positioning booster performed worse than the other restraint types. Lexvan, et al. [7] constrain a 6-year-old multi-rigid model on booster used MADYMO, studied the effect of seat belt slack on restraint system and the protective effect of pretension and force limiting belt on child occupant according to FMVSS 213 [8]. used Q3/Q3s and Hybrid a 3-year-old child dummy to simulate the effect of CRS misuse on head and neck injury of 3-year-old child occupants in frontal and side impact crashes.

However, Hybrid ? child dummy and multi-rigid model are mostly used in the study, and only some of dynamic parameters such as acceleration, force and moment can be obtained. In this paper, a high biofidelity finite element model of 6-yearold children occupant developed with accurate Anatomical Characteristics is used to assess the head injury from the specific injury location and severity children according to the distribution of stress and strain. The results will help us compare and analyze the protective effect of forward-facing child seats and boosters for rear seat occupant of 6-year-old children in frontal impact crashes.

\section{Simulation Model}

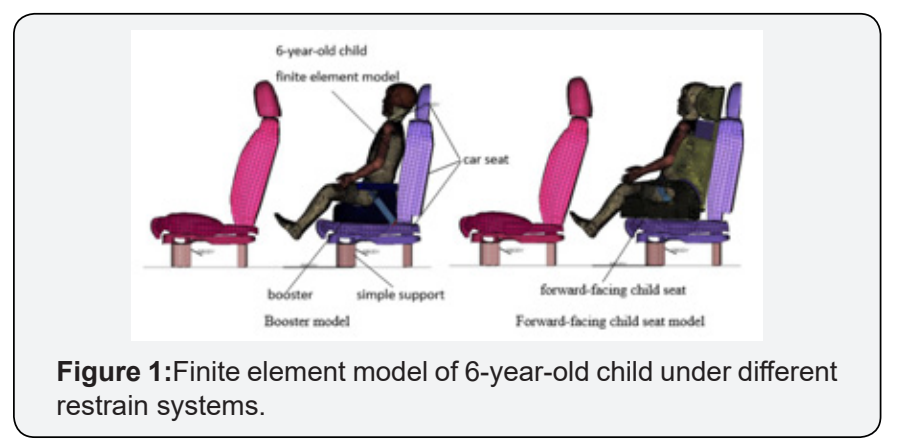

The finite element model of six-year-old child occupant (sitting posture) with accurate anatomical characteristics was developed and validated in previous research based on the real CT data, and the geometric model is meshed in Truegrid and Hypermesh. This model is joined by a total of 751,150 nodes and 737,729 elements, including 540,508 solid elements and 197,221 shell elements, and the total mass is $23.90 \mathrm{~kg}$. As shown in Figure 1 , the 6-year-old child finite element model was restrained on the booster and the forward-facing child seat respectively, and the lap shoulder belt is used for restraint in the booster model and 5-point safety belt is used for restraint in the forward-facing child seat model. The simulations scheme is shown in Table 1. The numerical simulations were completed using Pam-Crash, the gravity acceleration field of $9.8 \mathrm{~m} / \mathrm{s} 2$ and the deceleration curve were applied to the simulation model according to ECE R44 regulations.

Table 1: simulation schemes matrix.

\begin{tabular}{|c|c|c|}
\hline $\begin{array}{c}\text { Simulation } \\
\text { setting }\end{array}$ & Restrain form & Speed(km/h) \\
\hline Scheme 1 & Booster & 30 \\
\hline Scheme 2 & $\begin{array}{c}\text { Forward-facing } \\
\text { child seat }\end{array}$ & 30 \\
\hline Scheme 3 & Booster & 50 \\
\hline Scheme 4 & $\begin{array}{c}\text { Forward-facing } \\
\text { child seat }\end{array}$ & 50 \\
\hline Scheme 5 & Booster & 80 \\
\hline Scheme 6 & $\begin{array}{c}\text { Forward-facing } \\
\text { child seat }\end{array}$ \\
\hline
\end{tabular}

\section{Results}

\section{Head acceleration}

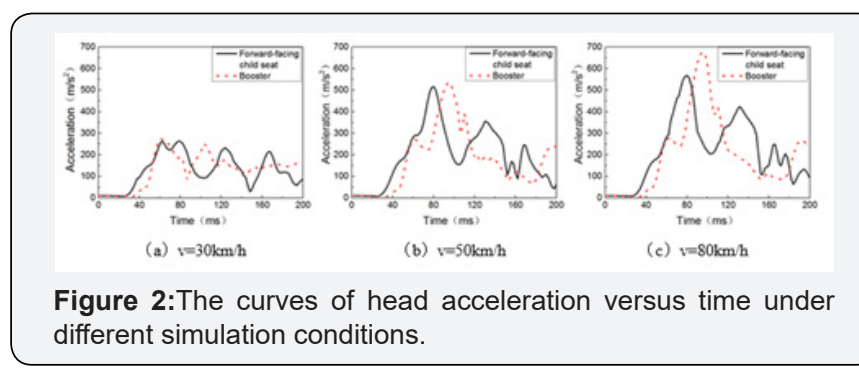

Table 2: Maximum values of resultant head acceleration and its discrepancy extent of two restrain systems.

\begin{tabular}{|c|c|c|c|}
\hline Speed km/h) & \multicolumn{2}{|c|}{$\begin{array}{c}\text { Max values of resultant head } \\
\text { acceleration/s }\end{array}$} & $\begin{array}{c}\text { discrepancy } \\
\text { extent }(\%)\end{array}$ \\
\hline & $\begin{array}{c}\text { forward-facing } \\
\text { child seat }\end{array}$ & booster & \\
\hline 30 & 265.44 & 275.23 & 3.69 \\
\hline 50 & 515.51 & 538.98 & 4.55 \\
\hline 80 & 568.93 & 676.5 & 18.71 \\
\hline
\end{tabular}

Note: The discrepancy extent is the percentage increase of the booster relative to the forward-facing child seat.

The curves of head acceleration versus time using two restraint systems under different simulation speeds (Figure 2). In the simulation by $30 \mathrm{~km} / \mathrm{h}$, the first wave peak, also known as the maximum, appears at the same time $(64 \mathrm{~ms})$ in both of restraint systems. When the collision speed was $50 \mathrm{~km} / \mathrm{h}$, the maximum values of the resultant head acceleration of the forward-facing 


\section{Open Access Journal of Neurology \& Neurosurgery}

child seat and booster were observed to be $515.51 \mathrm{~m} / \mathrm{s} 2$ and $538.98 \mathrm{~m} / \mathrm{s} 2$, and these peak values occurred at $80 \mathrm{~ms}$ and $94 \mathrm{~ms}$. When the collision speed was $80 \mathrm{~km} / \mathrm{h}$, the maximum values of the resultant head acceleration of the forward-facing child seat and booster were observed to be $568.93 \mathrm{~m} / \mathrm{s} 2$ and $676.50 \mathrm{~m} / \mathrm{s} 2$, and these peak values occurred at $80 \mathrm{~ms}$ and $96 \mathrm{~ms}$, respectively. Table 2 illustrates the maximum values of resultant head acceleration and its discrepancy extent of two restraint systems.

\section{Brain von mises stress}

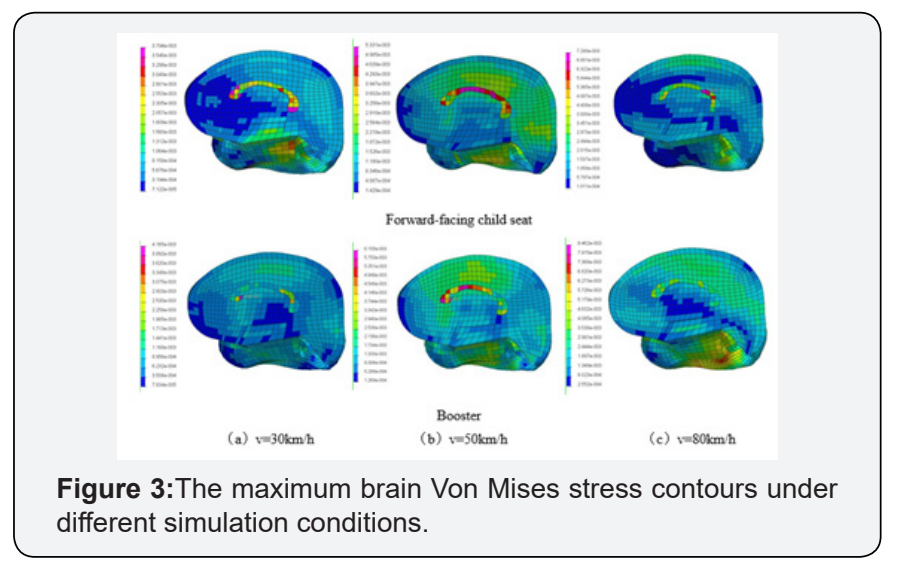

The maximum Von Mises stress contours of brain tissue (as shown in Figure 3) appeared in the corpus callosum, and stress concentration also occurred in soft tissue around the corpus callosum and bottom of brain tissue when the collision speed was $30 \mathrm{~km} / \mathrm{h}$ and $50 \mathrm{~km} / \mathrm{h}$ used both of restraint system. When the collision speed was $80 \mathrm{~km} / \mathrm{h}$, the maximum Von Mises stress in the forward-facing child seat was still presented in the corpus callosum, while in the booster it was appeared in the bottom of the brain tissue. Table 3 illustrates the maximum values of brain Von Mises stress and its discrepancy extent of two restraint systems. As can be seen from the table, the maximum Von Mises stress in the brain tissue of the forward-facing child seat was less than that of the booster at the same speed, and the discrepancy extent of two restrain systems was increases with the increase of speed.

Table 3: Maximum values of brain Von Mises stress and its discrepancy extent of two restrain systems.

\begin{tabular}{|c|c|c|c|}
\hline $\begin{array}{c}\text { Speed } \\
\mathbf{m} / \mathbf{h})\end{array}$ & \multicolumn{2}{|c|}{$\begin{array}{c}\text { Max values of brain Von Mises } \\
\text { stress }(\mathbf{k P a})\end{array}$} & $\begin{array}{c}\text { discrepancy } \\
\text { extent }(\%)\end{array}$ \\
\hline & $\begin{array}{c}\text { forward-facing } \\
\text { child seat }\end{array}$ & booster & \\
\hline 30 & 3.79 & 4.17 & 9.78 \\
\hline 50 & 5.33 & 6.15 & 15.38 \\
\hline 80 & 7.28 & 8.46 & 18.71 \\
\hline
\end{tabular}

\section{Intracranial pressure}

The maximum intracranial pressure of both restraint systems occurred in the corpus callosum, as shown in Figure 4, and there is a gradient change of intracranial pressure from the forehead to the occipital region. Table 4 illustrates the maximum intracranial pressure and its discrepancy extent of two restraint systems. With the increase of collision speed, the intracranial pressure in both of restraint systems also increase gradually, but at the same speed, the intracranial pressure in the forwardfacing child seat restraint system was smaller than that of the booster restraint system.

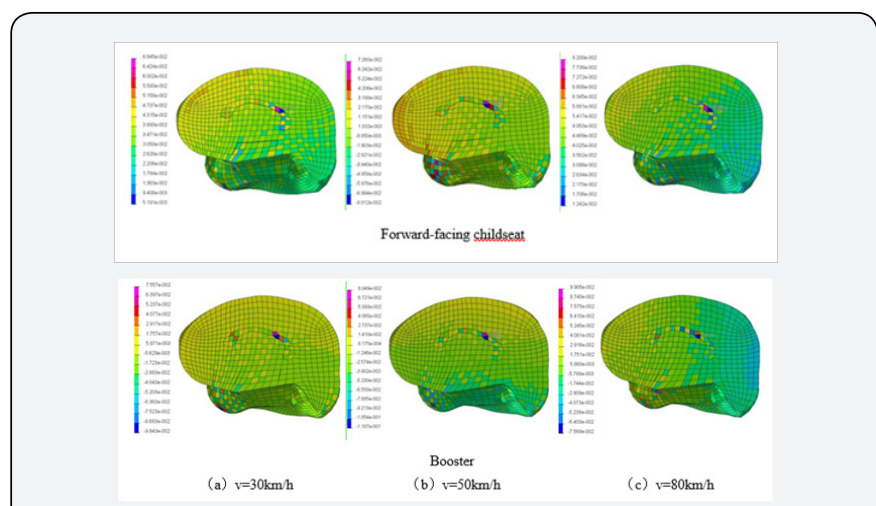

Figure 4:The maximum intracranial pressure contours under different simulation conditions.

Table 4: Maximum values of intracranial pressure and its discrepancy extent of two restrain systems.

\begin{tabular}{|c|c|c|c|}
\hline $\begin{array}{c}\text { Speed (k- } \\
\mathbf{m} / \mathbf{h})\end{array}$ & $\begin{array}{r}\text { Max values of Intracranial pres- } \\
\text { sure }(\mathbf{k P a})\end{array}$ & $\begin{array}{c}\text { discrepancy } \\
\text { extent }(\%)\end{array}$ \\
\hline & $\begin{array}{c}\text { forward-facing } \\
\text { child seat }\end{array}$ & booster & \\
\hline 30 & 68.45 & 75.57 & 10.4 \\
\hline 50 & 76.95 & 80.49 & 10.87 \\
\hline 80 & 82 & 99.05 & 20.79 \\
\hline
\end{tabular}

Brain shear stress

\section{Brain shear stress}
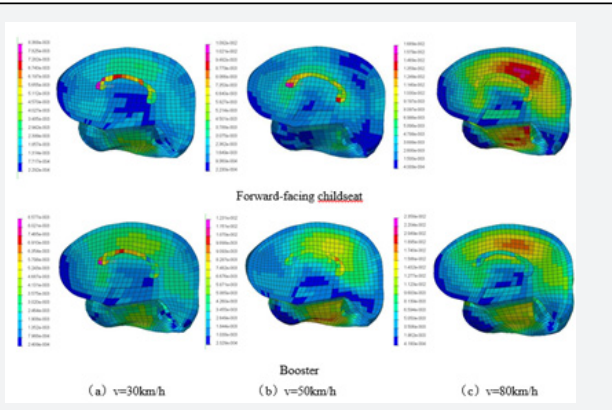

Figure 5:The maximum brain shear stress contours under different simulation conditions.

The maximum shear stress contours of brain tissue were mainly concentrated in the corpus callosum, soft tissue around the corpus callosum and the bottom of the brain tissue in Figure 5. And with the collision speed increased, the maximum shear stress in both restraint systems began to converge toward the cerebral white matter region above the corpus callosum and bottom of brain tissue. The maximum brain shear stress and its discrepancy extent of two restraint systems are showed in Table 5. The maximum brain shear stress in the two restrain systems is not large when speed was $30 \mathrm{~km} / \mathrm{h}$, and with the increase of 
collision speed, the discrepancy extent between the two restrain systems increase gradually. When the speed was $80 \mathrm{~km} / \mathrm{h}$, the discrepancy extent was approximately $39.61 \%$, and its effects can no longer be ignored.

Table 5: Maximum values of resultant head acceleration and its discrepancy extent of two restrain systems.

\begin{tabular}{|c|c|c|c|}
\hline $\begin{array}{c}\text { Speed (k- } \\
\mathbf{m} / \mathbf{h})\end{array}$ & \multicolumn{2}{|c|}{$\begin{array}{c}\text { Max values of brain shear } \\
\text { stress }(\mathrm{Kpa})\end{array}$} & $\begin{array}{c}\text { discrepancy } \\
\text { extent }(\%)\end{array}$ \\
\hline & $\begin{array}{c}\text { forward-facing } \\
\text { child seat }\end{array}$ & booster & \\
\hline 30 & 8.37 & 8.58 & 2.51 \\
\hline 50 & 10.92 & 12.31 & 12.73 \\
\hline 80 & 16.89 & 23.58 & 39.61 \\
\hline
\end{tabular}

Discussions

\section{Head acceleration}

It can be seen from Figure 2 (b) \& (c), the moment of reaching the peak acceleration of the head was later than that of the forward-facing child seat restraint system when the booster restraint system was used. At same time, the torso was restrained by the seat belt to stop forward movement, while the head continues to move under the action of inertia force, and the child occupant finite element model reached the maximum excursion. This is because of the seating height of the 6-yearold finite element model was $670 \mathrm{~mm}$, it's less than 50 percentile adult size, and the 3-point seat belt and the child finite element model do not fit very well, and there were some gaps between the two, due to the slack of seat belt, the wave crest is appears later relatively. However, when the forward-facing child seat restraint system was used, the head of the child finite element model will have a second collision with the headrest of the child seat during the rebound process, which leads to a second wave crest of the head acceleration.

\section{Intracranial pressure, von mises stress and shear stress of brain}

In this simulation the maximum Von Mises stress concentrated on the corpus callosum. This is consistent with Wang's experiment that Von Mises stress in brain tissue was mainly concentrated in the corpus callosum and its surrounding soft tissues when he carried out experiments on the head drops of 6-year-old child at different heights [9]. When the collision speed was $80 \mathrm{~km} / \mathrm{h}$, the maximum Von Mises stress in the booster constraint system appears at the bottom of brain tissue mainly because the rotation angle of the head during the collision was larger when the 3-point safety belt was used. With the increase of collision speed, the rotational load increases gradually, and the force exerted by the neck on the brain tissue increases, which makes the maximum Von Mises stress concentrate on the bottom of the brain tissue. However, the maximum value of the 5-point seat belt still appears in the corpus callosum due to its good restraint effect and the increase of collision speed has little effect on the rotation angle of the head.
Analyzing the simulation animation, the head of the child finite element model did not collide with the front seat due to the restraint of seat belt, but the Figure 4 indicated that the intracranial pressure in brain tissue also presented a certain gradient change under the combined action of linear acceleration and rotational acceleration. This further confirms Zheng's research linear acceleration and angular acceleration on the head and believed that both kinds of loads were the causes of intracranial pressure, and the influence of linear loads was greater than that of rotational loads [10].

Rosenblum, et al. [11] emphasized that the brain regions are a neural relay stations and an important functional center. If the shear stress in these regions was too large, it may lead to brain dysfunction, and shear stress was the main cause of Diffuse Axonal Injury (DAI). Holbourn, et al. [12] believed that relative to linear acceleration, angular acceleration was the main cause of brain tissue deformation and subsequent shear stress, and the shear stress of brain tissue was directly proportional to the rotational load it bears. Li et al. [13] stressed that when the head is subjected to angular acceleration, the structure of brain tissue distorts and produces shear stress due to the start time and speed of movement of deep and shallow brain tissue and different parts are inconsistent. With the increase of collision speed, the discrepancy extent of shear stress between the two restraint systems also increases. In this simulation, when the collision speed was $80 \mathrm{~km} / \mathrm{h}$, the difference is up to $39.61 \%$. Because there was a certain relaxation of the 3-point seat belt, the higher the speed, the more obvious of relaxation effect will be. As a result, the rotation load of the head of the child finite element model in the booster restraint system was too large, and the corresponding shear stress of brain tissue was too large.

\section{Conclusion}

In this paper, a validated 6-year-old child occupant finite element model with accurate anatomical characteristics is used to simulate the frontal crash in traffic accident. The head injury and the protective effect of different child restraint systems were investigated on the 6-year-old occupant in rear seat.

\section{An analysis of the observations acquired from the numerical simulations indicated the following:}

a. With the increase of collision speed, the head acceleration, intracranial pressure, brain Von Mises stress, brain shear stress increases gradually.

b. The forward movement excursion of the child finite element model is less than that of the 3-point seat belt due to the more close-fitting constraints of the 5-point safety belt. In the limited simulation time, the head of the child finite element model in forward-facing child seat will have a second collision with the headrest of the child seat during the rebound process, but because the child's head speed tends to ease, the secondary collision has little impact on the head injury indicators. 


\section{Open Access Journal of Neurology \& Neurosurgery}

c. When the collision speed is low, the degree of difference between the two restraint systems is not large. However, as the speed increases, the degree of difference increases gradually. When the speed reaches $80 \mathrm{~km} / \mathrm{h}$, such differences cannot be ignored. For children's safety considerations, 6-year-old children may still need to use forward-facing child seats.

\section{References}

1. (2016) National Highway Traffic Safety Administration.

2. Arbogast KB, Cornejo RA, Kallan MJ, Winston FK, Durbin DR (2002) Injuries to children in child restraints. Annu Proc Assoc Adv Automot Med 8(3): 277-284

3. Durbin DR, Kallan M, Winston FK (2001) Trends in booster seat use among children in crashes. Pediatric 108(6): e109.

4. Weber K (2000) Crash protection for child passengers: a review of best practice. UMTRI research review 31: (3).

5. Tanya Kapoor, William Altenhof, Qian Wang (2006) Injury potential of a three-year-old Hybrid III dummy in forward and rearward facing positions under CMVSS 208 testing conditions. Accident Analysis and Prevention 38(4): 786-800.

6. Rajiv Menon, Yoganand Ghati, Stephen Ridella (2004) Evaluation of Restraint Type and Performance Tested with 3-and 6-Year-Old Hybrid

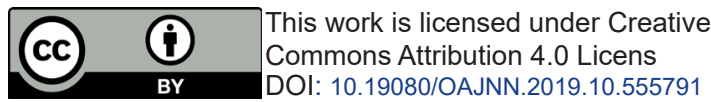

III Dummies at a Range of Speeds. SAE Technical Papers :113-122.

7. Lexvan Rooij, Christopher Sherwood (2008) The Effects of Vehicle Seat Belt Parameters on the Injury Risk for Children in Booster Seats. SAE transactions112(6): 470-482.

8. Tanya Kapoor, William Altenhof (2011) A numerical investigation into the effect of CRS misuse on the injury potential of children in frontal and side impact crashes. Accident Analysis and Prevention :14381450 .

9. Wang Chen (2015) Analysis of craniocerebral injury in six-year-old child finite element model. Tianjin: Tianjin University of Science \&Technology.

10. Liying Zhang, King H Yang, Albert I King (2004) A proposed injury threshold for mild traumatic brain injury. J Biomech Eng 2(126): 226 236.

11. Rosenblum W, Greenberg R, Seelig J, et al. (1981) Midbrain lesion: Frequent and significant prognostic feature in closed brain injury. Neurosurgery 9(6): 613-620.

12. Holbourn AHS (1943) Mechanics of head injuries. British Medical Bulletin 3(6): 147-149.

13. Li Haiyan, Zhao wei, Ruan Shijie, et al. (2012) Finite element evaluation on skull-brain relative displacement of the 95th percentile Chinese human head. Journal of Medical Biomechanics 27(2): 198-206.

\section{Your next submission with Juniper Publishers will reach you the below assets}

- Quality Editorial service

- Swift Peer Review

- Reprints availability

- E-prints Service

- Manuscript Podcast for convenient understanding

- Global attainment for your research

- Manuscript accessibility in different formats ( Pdf, E-pub, Full Text, Audio)

- Unceasing customer service

\section{Track the below URL for one-step submission}

https://juniperpublishers.com/online-submission.php 